\title{
Study of the Copper Corrosion Mechanism in the Presence of Propionic Acid Vapors
}

\author{
Alejandro Echavarría,* Felix Echeverría, Carlos Arroyave and Harveth Gil \\ Corrosion and Protection Group, University of Antioquia, Calle 62 No. 52-59, Lab. 330, \\ Sede de Investigación Universitaria, Medellín, Colombia
}

\begin{abstract}
O mecanismo da interação entre o cobre e os vapores do ácido propiônico é apresentado. As exposições foram realizadas em diferentes tempos e concentração de poluentes. Varredura Catódica, XRD e SEM foram usados para quantificar o grau de deterioração. Os resultados obtidos foram explicados pelo seguinte mecanismo: Uma camada do cuprita $\left(\mathrm{Cu}_{2} \mathrm{O}\right)$ é formada imediatamente. Este composto, na presença da água adsorvida é oxidado a tenorita $(\mathrm{CuO}) \mathrm{com}$ aumento do $\mathrm{pH}$. A hidratação da camada de tenorita beneficia a formação de um hidróxido $\mathrm{CuO} \cdot \mathrm{xH}_{2} \mathrm{O}$. Enquanto o nível do poluente é aumentado, o propionato básico insolúvel é formado $\left(\mathrm{Cu}(\mathrm{OH})_{\mathrm{x}}(\mathrm{Pro})_{2-\mathrm{x}}\right)$. Concentrações mais elevadas de ácido propiônico acidificam as mono camadas e um composto novo $\mathrm{Cu}$ (Pro) ${ }_{2} \cdot \mathrm{H}_{2} \mathrm{O}$ começa a se precipitar em $\mathrm{pH}$ baixo. Este é o constituinte principal da pátina verdeoliva formada nessas condições. Este mecanismo concorda, em termos gerais, com os propostos em trabalhos precedentes visando estudar a interação entre o cobre e os ácidos acético e fórmico.
\end{abstract}

The interaction mechanism between copper and propionic acid vapors is shown. Exposures were carried out to various pollutant concentrations and times. Cathodic scan, x-ray diffraction (XRD) and scanning electrode microscope (SEM) were used to quantify the degree of deterioration. The results obtained were explained by the following mechanism: A cuprite $\left(\mathrm{Cu}_{2} \mathrm{O}\right)$ layer covers the copper surface immediately; this compound in presence of adsorbed water is oxidized to tenorite $(\mathrm{CuO})$. The hydration of the tenorite layer benefits the formation of a hydroxide compound such as $\mathrm{CuO} \cdot \mathrm{xH}_{2} \mathrm{O}$. As the pollutant level is increased, insoluble basic propionate is formed $\left(\mathrm{Cu}(\mathrm{OH})_{x}\left(\mathrm{CH}_{3} \mathrm{CH}_{2} \mathrm{COO}\right)_{2-\mathrm{x}}\right)$. Higher concentrations of propionic acid acidify the monolayers and a new compound $\mathrm{Cu}\left(\mathrm{CH}_{3} \mathrm{CH}_{2} \mathrm{COO}\right)_{2} \cdot \mathrm{H}_{2} \mathrm{O}$ begins to precipitate at low $\mathrm{pH}$, this is the main constituent of the green olive patina formed under these conditions. This mechanism agrees, in general terms, with those proposed in previous works to study the interaction between copper and the acetic and formic acids.

Keywords: atmospheric corrosion, copper, organic acids, propionic acid, tropicorr

\section{Introduction}

Organic compounds are present in different phases in the atmosphere, and the most important organic acids that have been found are the formic, acetic, propionic, butyric and oxalic acids. The corrosion originated by these vapors on different metals and their alloys (lead, steel, nickel, copper, cadmium, magnesium, zinc) is a phenomenon that has been observed for some time. ${ }^{1}$ Copper is corroded in presence of these compounds such as formic, acetic and butyric. $^{2-9}$

Several studies has been performed to follow copper corrosion in presence of organic acids, and it has been

*e-mail: aechave@udea.edu.co; fecheve@udea.edu.co found that the corrosivity of the organic acids vapors in ppmv (parts per million in volume) on copper is given by the following order (from the highest to the lowest level of aggressiveness) acetic $>$ formic $>$ butyric. ${ }^{6,8,9}$ At the same time, the mechanism of degradation of copper in these acids includes the formation of a basic copper acetate and an hydrate copper acetate, copper formate and copper butyrate. ${ }^{6,8,9}$ The effect of these acids is enhanced during indoor conditions, were small quantities of this type of acids are found and can produce deterioration on copper and its alloys. The aim of this study is to evaluate and provided a better understanding by which copper is corroded in presence of propionic acid vapors. The work has been carried out by mean of electrochemical methods and characterization techniques such as XRD and SEM. 


\section{Experimental}

To study of the mechanism between copper and the propionic acid vapors two corrosive atmospheres were used: the first one was carried out in a climatic chamber with a pollutant level of ppb (parts per billion), under dynamic conditions. The second one was carried out under high concentration levels (parts per millions, ppm), using a closed chamber under static conditions.

\section{Exposures in the climatic chamber}

The climatic chamber is attached to an "oil-less" compressor used for dentistry; it provides air to a pretreatment system made of an activated carbon filter, a "PEAK" air purifier and two particulate material filters $(0.25$ and $0.05 \mu \mathrm{m})$. The purified air is separated in two streams that go to the humidifier, to the emission tube containing pure propionic acid or directly to the chamber for further air mixing. Different ratios of dry/humid air are regulated by needle valves to get the desired relative humidity (RH), and the mixing is performed in the chamber. Usually values of $90 \pm 2 \% \mathrm{RH}$ and $70 \pm 2.5 \% \mathrm{RH}$ were obtained. The chamber has a temperature control, and the polluted air goes through a desiccator where the samples were located. A constant air flow of $4 \mathrm{~L} \mathrm{~min}^{-1}$ was used. Emission tubes for the liquid propionic acid were used with different emission rates, gravimetrically certificated. The tubes were made of Pyrex of $3 \mathrm{~mm}$ of diameter and $90 \mathrm{~mm}$ high. They were sealed in one side and were made a tiny hole of approximately $10-50 \mu \mathrm{m}$ at the other side of the tube. This allows small emission rates of the acid, following the procedure describe by Lucero. ${ }^{10}$ The tubes were weighted before and after the exposure in order to estimate the actual emission rate of the acid. To obtain the concentration of the propionic acid as a vapor, an ideal gas behavior was assumed for the air of the system, ${ }^{11}$ the concentration of propionic acid in the vapor phase, can be calculated as:

$C v=\frac{E R * 29.5}{4 * 74.08}$

Where, $\mathrm{Cv}$ is the concentration of the propionic acid, expressed in parts per billion in volume (ppbv), ER is the emission rate of the glass tubes containing pure propionic acid $\left(2650 \pm 70,3750 \pm 80\right.$ and $\left.6950 \pm 100 \mathrm{ng} \mathrm{min}^{-1}\right)$, 29.5 is the molar volume $\left(\mathrm{L} \mathrm{mol}^{-1}\right)$ of the air at laboratory conditions, $30^{\circ} \mathrm{C}$ and $640 \mathrm{~mm} \mathrm{Hg}$ is the local atmospheric pressure (Medellin, Colombia 1450 ASL), 4 is the nominal air flow $\left(\mathrm{L} \mathrm{min}^{-1}\right)$ and 74.08 is the molecular weight $\left(\mathrm{g} \mathrm{mol}^{-1}\right)$ of the propionic acid $\left(\mathrm{CH}_{3} \mathrm{CH}_{2} \mathrm{COOH}\right)$.
Copper coupons were plates sized $1.0 \times 1.5 \times 0.01 \mathrm{~cm}$, Merck $(<0.002 \%$ Ag, $0.05 \%$ Pb, $0.01 \%$ Sn, $0.005 \%$ $\mathrm{Fe}, 0.005 \% \mathrm{Mn}, 0.0002 \% \mathrm{As})$, polished with different abrasive papers up to 600 mesh and then degreased with acetone, dried with air and immediately placed in the exposure chamber. The coupons were hanging vertically perpendicular to the air flow inside a glass vessel and exposed to propionic acid for 7,14 , and 21 days. Three concentrations of propionic acid were used (260, 380 and 690 ppbv).

\section{Exposures in closed chamber}

Static conditions experiments were performed under 4, 20, 40, and $120 \mathrm{ppmv}$ propionic acid concentration at $30 \pm 0.8{ }^{\circ} \mathrm{C}$ during 21 days. For low relative humidity conditions, it was employed in the desiccator a saturated solution of $\mathrm{K}_{2} \mathrm{CO}_{3} \cdot 2 \mathrm{H}_{2} \mathrm{O}$ and $\mathrm{NH}_{4} \mathrm{Cl}$ to obtain $40 \% \mathrm{RH}$ and $80 \%$ RH according to the ASTM E104-85 standard. ${ }^{7}$ The relative humidity condition near $100 \%$ was obtained placing a recipient with $500 \mathrm{~mL}$ of propionic acid solution at the bottom of the desiccator. In these experiments the propionic acid vapor was produced, following the procedure described in previous works ${ }^{2-9}$ and in any case, solutions were renewed weekly to prevent degradation of the organic compound.

The concentration (in volume) of the propionic acid vapor in closed atmosphere was calculated using the relationship of partial pressures and Raoult's law. ${ }^{2-9}$

$C v=\frac{p_{H(\mathrm{Pr} o)}}{P_{T}}=\frac{G \cdot M_{H_{2} \mathrm{O}}}{1000 \cdot M_{H\left(\mathrm{Pr}_{\mathrm{o}}\right)} P_{T}} \cdot 10^{8.8519-\frac{2454.02}{T}}$

Where: the term $10^{8.8519}-\frac{2454.02}{T}$ is the vapor partial pressure of pure propionic acid $(\mathrm{mm} \mathrm{Hg}), \mathrm{pH}_{\text {(Pro) }}$ is the partial pressure of the propionic acid in the desiccator atmosphere, $\mathrm{T}$ is the temperature in $\mathrm{K}, \mathrm{G}$ is the mass of the propionic acid in grams in a $1000 \mathrm{~mL}$ solution, $\mathrm{M}_{\mathrm{H}_{2} \mathrm{O}}$ and $\mathrm{M}_{\mathrm{H}(\mathrm{Pro})}$ are the molecular weights of water and propionic acid and $\mathrm{P}_{\mathrm{T}}$ is the total pressure under the laboratory conditions $(640 \mathrm{~mm} \mathrm{Hg})$.

For exposures in atmospheres with 4, 20, 40, and $120 \mathrm{ppmv}(\mathrm{Cv})$, the amounts of propionic acid and water used for a volume of $500 \mathrm{~mL}$ solution are shown in Table 1.

Table 1. Amount of propionic acid added to $500 \mathrm{~mL}$ of water to obtain the different concentrations used in this study: 4, 20, 40, and $120 \mathrm{ppmv}$

\begin{tabular}{lcrrr}
\hline Concentration of the acid in the air / ppmv & 4 & 20 & 40 & 120 \\
Amount of propionic acid / mL & 0.9 & 4.6 & 9.3 & 27.9 \\
Amount of water / mL & 499.1 & 495.4 & 490.7 & 472.1 \\
\hline
\end{tabular}




\section{Characterization techniques}

Cathodic scan, XRD and SEM were used to characterize the corrosion products. Cathodic scan experiments were carried out with a BAS ZAHNER potenciostat at a scan rate of $0.001 \mathrm{~V} \mathrm{~s}^{-1}$ between the corrosion potential and $-1.5 \mathrm{~V}_{\mathrm{SCE}}$. The reductions were performed by using three electrodes with the saturated calomel electrode (SCE) as reference and platinum as counter electrode. A solution of $0.1 \mathrm{~mol} \mathrm{~L}^{-1}$ $\mathrm{KCl}$ was used as support electrolyte purged with $\mathrm{N}_{2}$ grade 5 for $30 \mathrm{~min}$ before the test and keeping bubbling during the scans. Cathodic scan curves of the coupons exposed to the different atmospheres were compared with those obtained from ex situ conditions. The ex situ compounds were produced by anodic polarizations to different potentials and a scan rate of $1 \mathrm{mV} \mathrm{s}^{-1}$. Polarizations were performed in 0.01 and $0.1 \mathrm{~mol} \mathrm{~L}^{-1} \mathrm{NaOH}$ until 0.2 and $0.9 \mathrm{~V}_{\mathrm{SCE}} 0.01 \mathrm{~mol} \mathrm{~L}^{-1}$ $\mathrm{Cu}\left(\mathrm{CH}_{3} \mathrm{CH}_{2} \mathrm{COO}\right)_{2} \mathrm{H}_{2} \mathrm{O}$ until $0.9 \mathrm{~V}$ and 0.01 and $0.1 \mathrm{~mol} \mathrm{~L}^{-1}$; $\mathrm{CH}_{3} \mathrm{CH}_{2} \mathrm{COOH}$ until 0.2 and $0.9 \mathrm{~V}_{\mathrm{SCE}}$. Once the polarization reaches the desired potential, the sample was took out and immediately placed in the electrochemical cell where the reduction was performed. Each anodic polarization was made by triplicate. The corrosion products of coupons exposed to 40 and 120 ppmv pollutant concentration and $100 \% \mathrm{RH}$, were analyzed by XRD. The diffractograms were performed in a Bruker D8 Advance diffractometer and SEM micrographs were obtained in a Hitachi S-500 electronic scan microscope.

\section{Results and Discussion}

Figure 1 shows the appearance of the copper coupons surfaces after exposure during 21 days to different conditions of pollutant concentration and relative humidity. As it can be observed, the color surface varies from a pale yellow to an olive green, typical of the copper propionate patinas obtained in more polluted atmospheres (120 ppmv) and $100 \%$ RH. An important characteristic of these green patinas is their solubility in watery solutions. The outer part of the patina containing hydrated or basic copper propionates is very soluble but the inner part is usually composed of copper oxides or hydroxides that remain on the surface being possible to detect them by electrochemical reduction.

In Figure 2 the cathodic scans of copper coupons exposed to $260 \mathrm{ppbv}, 70 \% \mathrm{RH}$ during 21 are compared with the anodic compounds formed in 0.01 and $0.1 \mathrm{~mol} \mathrm{~L}^{-1}$ $\mathrm{NaOH}$ solutions obtained from polarization up to $0.2 \mathrm{~V}_{\mathrm{SCE}}$ (right axis), all curves were obtained using $0.1 \mathrm{~mol} \mathrm{~L}^{-1}$ $\mathrm{KCl}$ as supporting electrolyte. It can be observed that the corrosion products in the $260 \mathrm{ppbv}$ and $70 \% \mathrm{RH}$ condition

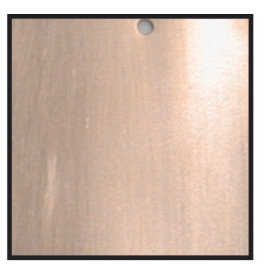

(a)

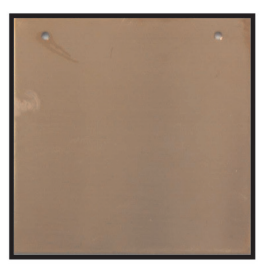

(d)

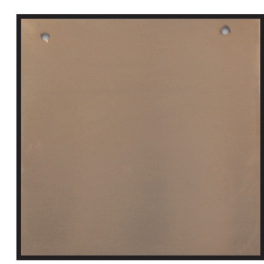

(g)

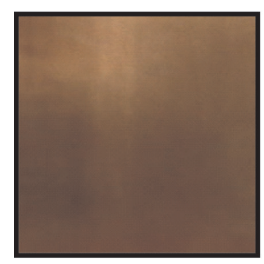

(j)

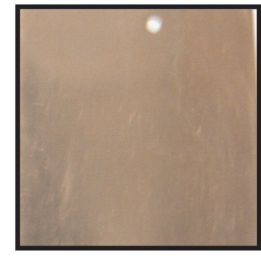

(b)

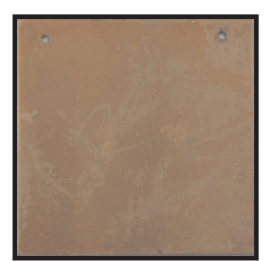

(e)

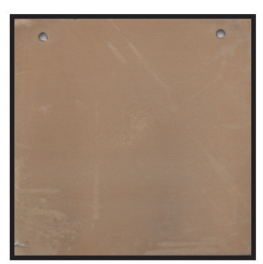

(h)

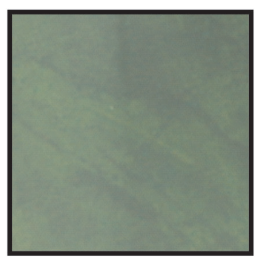

(k)

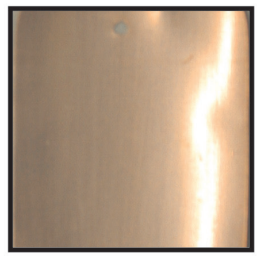

(c)

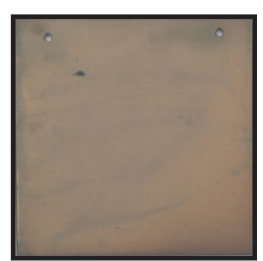

(f)

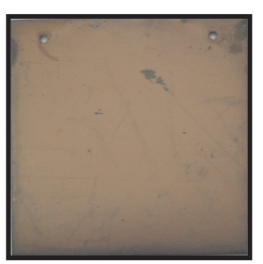

(i)

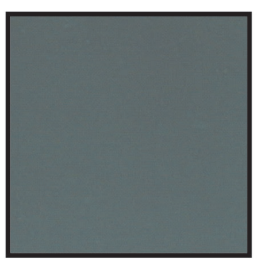

(1)
Figure 1. Appearance of the copper coupons of an unexposed sample (a), and exposed to different conditions during 21 days: 260 ppbv-70\% RH (b); 380 ppbv-90\% RH (c); 4 ppmv-40\% RH (d); 40 ppmv-40\% RH (e); 120 ppmv-40\% RH (f); 4 ppmv-80\% RH (g); 40 ppmv-80\% RH (h); 120 ppmv-80\% RH (i); 4 ppmv-100\% RH (j); 40 ppmv-100\% RH (k); 120 ppmv-100\% RH (1).

are more similar to the anodic compound formed in the $0.01 \mathrm{~mol} \mathrm{~L}^{-1} \mathrm{NaOH}$ solutions than the one obtained in $0.1 \mathrm{~mol} \mathrm{~L}^{-1} \mathrm{NaOH}$. In this sort of conditions, compounds such as $\mathrm{Cu}_{2} \mathrm{O} / \mathrm{Cu}(\mathrm{OH})_{2} / \mathrm{CuO}$ are found. ${ }^{11,12}$ The peak seen in propionic acid exposures scans at $-0.48 \mathrm{~V}_{\mathrm{SCE}}$ is related to amorphous copper (I) oxide ${ }^{13-16}\left(\mathrm{Cu}_{2} \mathrm{O}\right)_{\text {am }}$ and the peak around $-0.8 \mathrm{~V}_{\mathrm{SCE}}$ is related to crystalline copper (I) oxide $\left(\mathrm{Cu}_{2} \mathrm{O}\right)_{\text {cr }}{ }^{13,17-20}$

Figure 3 compares cathodic scan curves of copper coupons exposed to $680 \mathrm{ppbv}$ at $90 \% \mathrm{RH}$ during 21 days with those obtained by anodic polarizations in $0.01 \mathrm{~mol} \mathrm{~L}^{-1}$ $\mathrm{NaOH}$ (polarized up to $0.2 \mathrm{~V}_{\mathrm{SCE}}$ ) and $0.01 \mathrm{~mol} \mathrm{~L}^{-1}$ $\mathrm{Cu}\left(\mathrm{CH}_{3} \mathrm{CH}_{2} \mathrm{COO}\right)_{2}$ (polarized up to $0.2 \mathrm{~V}_{\mathrm{SCE}}$ and $0.9 \mathrm{~V}_{\mathrm{SCE}}$ ) solutions. The corresponding curve of the anodic compound obtained in $0.01 \mathrm{~mol} \mathrm{~L}^{-1} \mathrm{CH}_{3} \mathrm{CH}_{2} \mathrm{COOH}$ polarized up to $0.9 \mathrm{~V}_{\mathrm{SCE}}$ is also shown. It is observed that the anodic compound formed in $0.01 \mathrm{~mol} \mathrm{~L}^{-1} \mathrm{Cu}\left(\mathrm{CH}_{3} \mathrm{CH}_{2} \mathrm{COO}\right)_{2}$ 


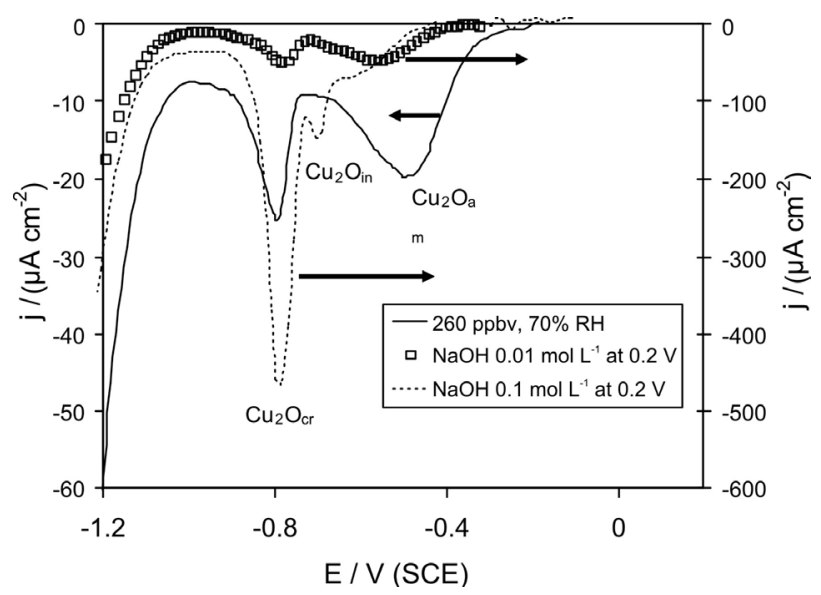

Figure 2. Cathodic scans of copper exposed to $260 \mathrm{ppbv}, 70 \% \mathrm{RH}$ during 21 days (left axis) compared with the anodic compounds formed in $0.01 \mathrm{~mol} \mathrm{~L}^{-1}$ and $0.1 \mathrm{~mol} \mathrm{~L}^{-1} \mathrm{NaOH}$ solutions polarized up to $0.2 \mathrm{~V}_{\mathrm{SCE}}$ (right axis); $0.1 \mathrm{~mol} \mathrm{~L}^{-1} \mathrm{KCl}$ was the support electrolyte.

solution (pH 4.8) and polarized up to $0.9 \mathrm{~V}_{\mathrm{SCE}}$ shows two reduction peaks located in $-0.62 \mathrm{~V}_{\mathrm{SCE}}$ and $-0.88 \mathrm{~V}_{\mathrm{SCE}}$. These are attributed to intermediate and crystalline copper (I) oxide, respectively. ${ }^{21}$ The intermediate copper (I) oxides is a phase formed through transformation of the amorphous oxide into the crystalline oxide. Likewise, the compound formed in $0.01 \mathrm{~mol} \mathrm{~L}^{-1} \mathrm{CH}_{3} \mathrm{CH}_{2} \mathrm{COOH}$ solutions ( $\mathrm{pH} 3.5$ ) is close to the peak observed at $0.9 \mathrm{~V}_{\mathrm{SCE}}$ from the $680 \mathrm{ppbv}$ and $90 \% \mathrm{RH}$ coupons. According with these results, the compound that appear at $0.9 \mathrm{~V}_{\mathrm{SCE}}$ is related to the anodic compound that form in propionate solutions, with or without the presence of cupric ions. This compound ${ }^{12}$ is probably a crystalline copper (I) oxide produced by the formation of a copper propionate that remains in the inner side of the patina. Therefore, in this type of conditions a $\mathrm{Cu} / \mathrm{Cu}_{2} \mathrm{O}$ layer is found. ${ }^{22}$

Figure 4 shows the cathodic scan curves corresponding to the exposures of copper coupons during 21 days at

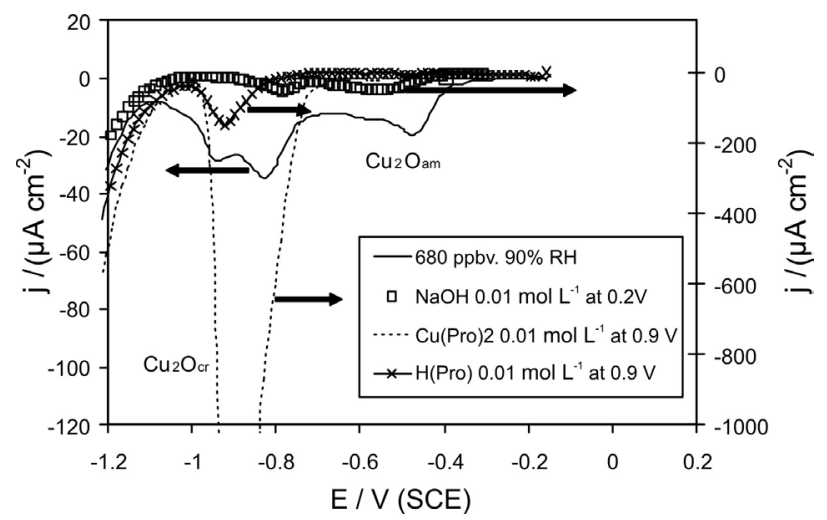

Figure 3. Comparison of cathodic scan curves of copper exposed to $680 \mathrm{ppbv}$ and $90 \%$ RH during 21 days of exposure (left axis) with those obtained of anodic compounds formed in $0.1 \mathrm{~mol} \mathrm{~L}^{-1} \mathrm{NaOH}\left(0.2 \mathrm{~V}_{\mathrm{SCE}}\right)$, $0.01 \mathrm{~mol} \mathrm{~L}^{-1} \mathrm{Cu}\left(\mathrm{CH}_{3} \mathrm{CH}_{2} \mathrm{COO}\right)_{2}\left(0.2 \mathrm{~V}_{\mathrm{SCE}}\right.$ and $\left.0.9 \mathrm{~V}_{\mathrm{SCE}}\right)$ solutions (right axis).

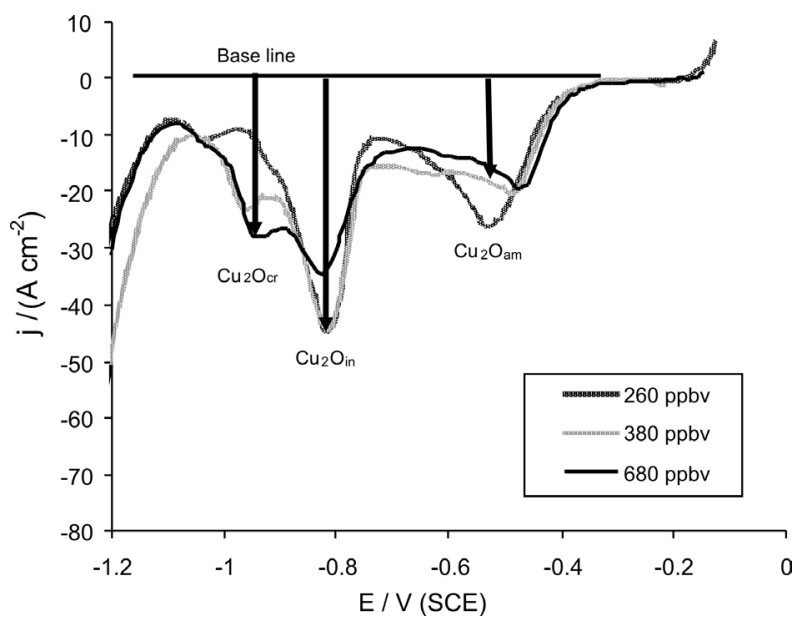

Figure 4. Cathodic scan curve for 21 days of exposure under dynamic conditions $260 \mathrm{ppbv}, 380 \mathrm{ppbv}$, and $680 \mathrm{ppbv}$ with relative humidity of $90 \% \mathrm{RH}$ at $30^{\circ} \mathrm{C}$.

$260 \mathrm{ppbv}, 380 \mathrm{ppbv}$ and $680 \mathrm{ppbv}$, with a relative humidity of $90 \% \mathrm{RH}$. The presence of reduction peaks, at relatively well defined potentials of $-0.5 \mathrm{~V}_{\mathrm{SCE}},-0.8 \mathrm{~V}_{\mathrm{SCE}}$ and $-0.9 \mathrm{~V}_{\mathrm{SCE}}$ can be observed as before. In similar way, all the curves exhibit the beginning of hydrogen reduction at potentials below $-1.2 \mathrm{~V}_{\mathrm{SCE}}$.

Therefore, the reduction sequence proposed for the cathodic scan of samples exposed in $90 \% \mathrm{RH}$ and 260 to 680 ppbv atmospheres is: $\mathrm{Cu}_{2} \mathrm{O}_{\text {am }}, \mathrm{Cu}_{2} \mathrm{O}_{\text {in }}$ and $\mathrm{Cu}_{2} \mathrm{O}_{\text {cr }}$; in this case, amorphous cuprite, intermediate cuprite and crystalline cuprite. The presence of copper (II) oxide (tenorite) is also possible but in small quantities. The presence of these oxides is explained according to the same interval of potential and the stable area predictions in the Pourbaix diagram. ${ }^{11,23} \mathrm{~A}$ basic copper propionate that is seen with the XRD results (discussed latter on Page 6) do not remains on the copper surface to be detected by the electrochemical reduction. The small displacement seen for the same compounds obtained in different pollutant conditions could be related to formation of more stable compounds as the propionic acid concentration increases. Atmospheres highly polluted can accelerate the copper oxides and propionate formation making the first ones more thermodynamically stable and therefore more difficult to reduce in $0.1 \mathrm{~mol} \mathrm{~L}^{-1} \mathrm{KCl}$.

Figure 5 compares cathodic scan curves of copper coupons exposed to $20 \mathrm{ppmv}$ of propionic acid vapor (at static conditions) and $100 \% \mathrm{RH}, 30^{\circ} \mathrm{C}$ during 7,14 , and 21 days with those obtained in ex situ conditions polarized up to $0.2 \mathrm{~V}_{\mathrm{SCE}}$ and $0.9 \mathrm{~V}_{\mathrm{SCE}}$ in $0.01 \mathrm{~mol} \mathrm{~L}^{-1}$ of copper propionate solution. In both cases the scans of the ex situ compounds only shows one reduction peak at $-0.9 \mathrm{~V}_{\mathrm{SCE}}$. Attribution of this peak to crystalline cuprite confirms the results obtained during dynamic conditions with an environment less 


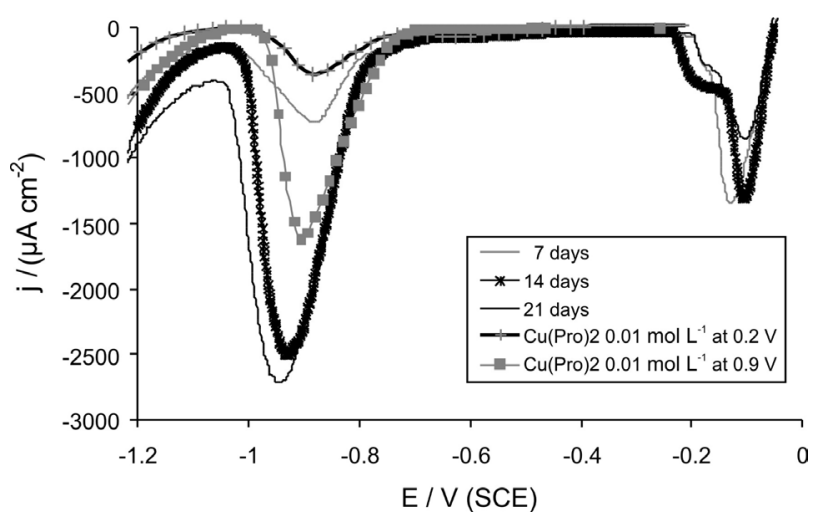

Figure 5. Comparison of cathodic scan curves of copper coupons exposed to $20 \mathrm{ppmv}$ of propionic acid vapor (static condition) and $100 \% \mathrm{RH}$, $30{ }^{\circ} \mathrm{C}$ for 7,14 , and 21 days with those obtained of anodic compounds formed in $0.01 \mathrm{~mol} \mathrm{~L}^{-1} \mathrm{Cu}\left(\mathrm{CH}_{3} \mathrm{CH}_{2} \mathrm{COO}\right)_{2}$ solutions (polarized to $0.2 \mathrm{~V}_{\mathrm{SCE}}$ and $\left.0.9 \mathrm{~V}_{\mathrm{SCE}}\right)$.

polluted (ppbv), already described. The peak seen around $-0.15 \mathrm{~V}_{\mathrm{SCE}}$ is associated to a basic copper (II) chloride, it is discussed later on.

Figure 6 compares the same cathodic scan curves of copper coupons exposed to $20 \mathrm{ppmv}$ of propionic acid vapor at static conditions, $100 \% \mathrm{RH}, 30{ }^{\circ} \mathrm{C}$ during 7,14 , and 21 days, with those obtained during ex situ conditions. The anodic compounds were polarized up to $0.1 \mathrm{~V}_{\mathrm{SCE}}$ and $0.2 \mathrm{~V}_{\mathrm{SCE}}$ in $0.01 \mathrm{~mol} \mathrm{~L}^{-1} \mathrm{KCl}$ as supporting electrolyte. It is observed that the anodic compound formed at $0.1 \mathrm{~V}_{\mathrm{SCE}}$ and $0.2 \mathrm{~V}_{\mathrm{SCE}}$ in $\mathrm{KCl}$ shows only one reduction peak located at $-0.2 \mathrm{~V}_{\mathrm{SCE}}$ and $-0.25 \mathrm{~V}_{\mathrm{SCE}}$ respectively. In a similar way, the copper patina exhibits a reduction peak located near $-0.15 \mathrm{~V}_{\mathrm{SCE}}$.

The presence of this peak could be due to a basic copper (II) chloride; similar to the one reported previously by Drogowska et al.,${ }^{24}$ in a study of anodic copper dissolution in presence of $\mathrm{Cl}^{-}$ions at $\mathrm{pH}$ 12. The formation of this compound probably occurs by the following mechanism: At the 20 ppmv conditions, as the basic copper propionate is solubilized by the $\mathrm{KCl}$ solution, the cupric ions are rejected at the electrodic interface during



Figure 6. Comparison of typical cathodic scan curves of copper coupons exposed to $20 \mathrm{ppmv}$ of propionic acid vapor ppbv (static condition) and $100 \% \mathrm{RH}, 30^{\circ} \mathrm{C}$ for 7,14 , and 21 days with those obtained of anodic compounds formed in $0.1 \mathrm{~mol} \mathrm{~L}^{-1} \mathrm{KCl}$ solutions (polarized to $0,0.1 \mathrm{~V}_{\mathrm{SCE}}$ and $\left.0.2 \mathrm{~V}_{\mathrm{SCE}}\right)$.

the initial seconds of immersion. The cupric ions can then react with the chloride and hydroxyl ions at the vicinities of these interfaces, positively charged. Once the basic copper (II) chloride is formed, it remains on the surface and it is possible that shifts the corrosion potential to more positive stages. This fact can be evidenced by the high corrosion potential, 0.2 $\mathrm{V}_{\text {SCE }}$ (Figure 5) compared with the corrosion potential at the ppbv condition near $-0.1 \mathrm{~V}_{\mathrm{SCE}}$ (Figures 2 and 3).

Table 2 shows the reduction currents associated to every peak in the cathodic scans for 21 days of exposure. As it can be seen, as the pollutant level is increased from $260 \mathrm{ppbv}$ up to $680 \mathrm{ppbv}$, the cathodic currents associated to the reduction of $-0.9 \mathrm{~V}_{\mathrm{SCE}}$ increase according to the degree of contamination whereas the currents associated to the reduction peaks at $-0.5 \mathrm{~V}_{\mathrm{SCE}},-0.6 \mathrm{~V}_{\mathrm{SCE}}$ and $-0.8 \mathrm{~V}_{\mathrm{SCE}}$ appears to be independent of the pollutant concentration. The reduction current associated to the $-0.9 \mathrm{~V}_{\mathrm{SCE}}$ peak is maximum at the higher level of propionic acid vapor pollutant (40 ppmv, static conditions). Therefore, the increment in the pollutant concentration shifts the curves to greater reduction currents referred to the base line.

Table 2. Current density $\left(\mu \mathrm{A} \mathrm{cm} \mathrm{cm}^{-2}\right.$ ) of the reduction peaks corresponding to the cathodic scans of copper coupons exposed during 21 days of exposure to different atmospheres under dynamic (ppbv) and static (ppmv) conditions

\begin{tabular}{|c|c|c|c|c|c|}
\hline Experimental conditions & $-0.9 \mathrm{~V}_{\mathrm{SCE}}$ & $-0.8 \mathrm{~V}_{\mathrm{SCE}}$ & $-0.6 \mathrm{~V}_{\mathrm{SCE}}$ & $-0.5 \mathrm{~V}_{\mathrm{SCE}}$ & $-0.15 \mathrm{~V}_{\mathrm{SCE}}$ \\
\hline $260 \mathrm{ppbv}, 70 \% \mathrm{RH}, 30^{\circ} \mathrm{C}$ & 0 & 15 & 10 & 15 & ------ \\
\hline $260 \mathrm{ppbv}, 90 \% \mathrm{RH}, 30^{\circ} \mathrm{C}$ & 0 & 40 & 15 & 25 & ------ \\
\hline 380 ppbv, $90 \% \mathrm{RH}, 30^{\circ} \mathrm{C}$ & 15 & 40 & 12 & 20 & ------ \\
\hline $680 \mathrm{ppbv}, 90 \% \mathrm{RH}, 30^{\circ} \mathrm{C}$ & 20 & 30 & 10 & 20 & ------ \\
\hline $680 \mathrm{ppbv}, 90 \% \mathrm{RH}, 35^{\circ} \mathrm{C}$ & 30 & 45 & 15 & 15 & ------ \\
\hline 4 ppmv, $100 \% \mathrm{RH}, 30^{\circ} \mathrm{C}$ & 190 & ------- & -------- & -------- & 1090 \\
\hline $40 \mathrm{ppmv}, 100 \% \mathrm{RH}, 30^{\circ} \mathrm{C}$ & 2630 & ------- & -------- & -------- & 730 \\
\hline
\end{tabular}


Figure 7 shows the XRD diffractograms of copper coupons exposed to $4,20,40$, and 120 ppmv of propionic acid vapors and $100 \%$ RH during 21 days. The non marked peaks, with a maximum intensity arounf eight degrees correspond to the $\mathrm{Cu}\left(\mathrm{CH}_{3} \mathrm{CH}_{2} \mathrm{COO}\right)_{2} \cdot \mathrm{H}_{2} \mathrm{O}$ according with the results obtained by Gómez et al. ${ }^{25}$ During the exposures at $120 \mathrm{ppmv}$ it was found that the copper propionate monohydrate constitutes most of thecorrosion products, with smaller amounts of the "x" compound (not identified in this work, probably a basic copper propionate), cuprite and paramelaconite. At $40 \mathrm{ppmv}$, the copper propionate monohydrate is the compound that appears to be more abundant, followed in importance by cuprite and paramelaconite. At $20 \mathrm{ppmv}$, the copper propionate monohydrate is still the most predominant compound, but another compound appears ("y", non identified) with smaller amounts of cuprite and paramelaconite.

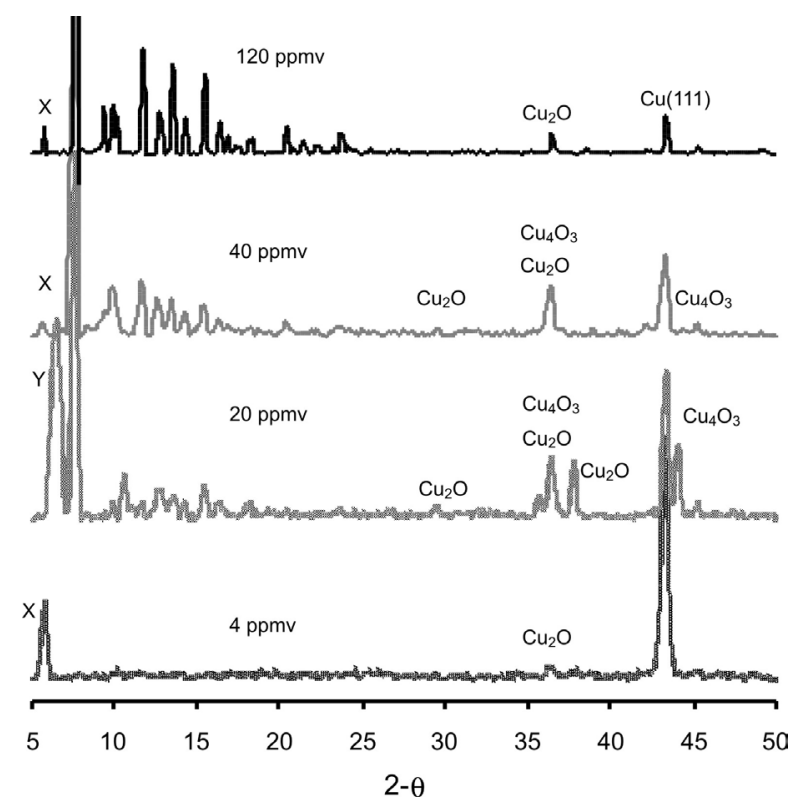

Figure 7. XRD diffractogram $\left(\mathrm{Cu}_{\mathrm{K} \alpha}\right)$ of copper exposed to $4,20,40$, and 120 ppmv of propionic acid vapors and $100 \% \mathrm{RH}$ during 21 days. The non marked peaks correspond to the $\mathrm{Cu}\left(\mathrm{CH}_{3} \mathrm{CH}_{2} \mathrm{COO}\right)_{2} \cdot \mathrm{H}_{2} \mathrm{O}$.

In figure 8 the scanning electron micrograph of the structure of the superficial corrosion products is evidenced. When copper is exposed at 40 ppmv of propionic acid vapors the cuprite crystals appear in aggregates, with crystalline habits in form of lengthened prisms. In this case, the granular surface is composed by the copper propionate. With exposures at 120 ppmv of propionic acid vapors, the scanning electron micrograph shows cuprite crystals (2\%) with its characteristic habit in form of diamonds or cuboids. However, the increase in crystallinity of $\mathrm{Cu}\left(\mathrm{CH}_{3} \mathrm{CH}_{2} \mathrm{COO}\right)_{2} \cdot \mathrm{H}_{2} \mathrm{O}$, detected by the XRD data, does not become evident and it also appears as granular form.

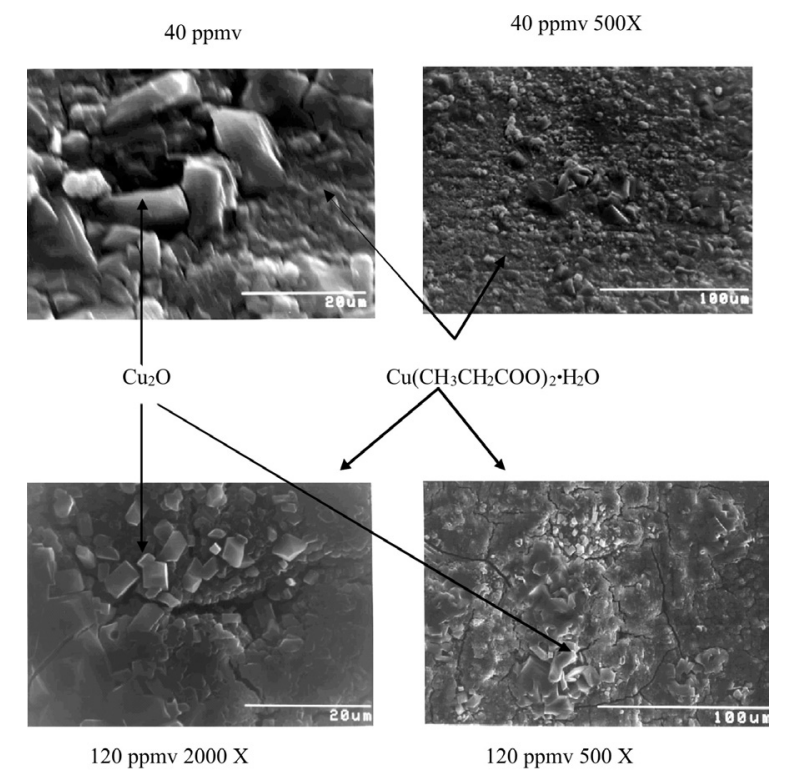

Figure 8. SEM micrograph of copper exposed to propionic acid vapors at 120 ppmv for 21 days.

Interaction mechanism between pure copper and propionic acid vapors

A cuprite layer $\left(\mathrm{Cu}_{2} \mathrm{O}\right)$ is instantly formed on the copper surface by air exposure. The temperature and relative humidity of the atmospheric air can cause the condensation of water vapor on the copper surface. The thickness of the aqueous layer is increased when increasing the air relative humidity. At low concentrations of propionic acid in environment, oxidation of cuprite to tenorite is carried out with the reduction of the oxygen in the water, according to the following reactions:

$$
\begin{aligned}
& \mathrm{Cu}_{2} \mathrm{O}+\mathrm{H}_{2} \mathrm{O} \rightarrow 2 \mathrm{CuO}+2 \mathrm{H}^{+}+2 \mathrm{e}^{-} \\
& 1 / 2 \mathrm{O}_{2}+\mathrm{H}_{2} \mathrm{O}+2 \mathrm{e}^{-} \rightarrow 2 \mathrm{OH}^{-}
\end{aligned}
$$

To produce the net reaction:

$\mathrm{Cu}_{2} \mathrm{O}+1 / 2 \mathrm{O}_{2} \rightarrow 2 \mathrm{CuO}$

The positively charged anodic areas where the $\mathrm{CuO}$ formation occurs, attract towards the metal-monolayer interface, the hydroxyl ions negatively charged $\left(\mathrm{OH}^{-}\right)$ causing an increase of the local $\mathrm{pH}$. Under these conditions, the $\mathrm{CuO}$ can be hydrolyzed and forms copper hydroxide:

$\mathrm{CuO}+\mathrm{H}_{2} \mathrm{O} \rightarrow \mathrm{Cu}(\mathrm{OH})_{2}$

Therefore, the first corrosion products that are formed correspond to a stratified mixture of $\mathrm{Cu}_{2} \mathrm{O}-\mathrm{CuO}-\mathrm{Cu}(\mathrm{OH})_{2}$ 
or $\mathrm{CuO} \cdot \mathrm{xH}_{2} \mathrm{O} .^{9,22}$ This structure goes from the internal interface metal-patina up to the external interface patinaatmosphere. The cathodic scan curves of copper coupons exposed to $680 \mathrm{ppbv}, 90 \% \mathrm{RH}$ for 21 days, (Figure 3) show the reduction peaks corresponding to three copper (I) oxides, namely amorphous at $-0.5 \mathrm{~V}_{\mathrm{SCE}}$, intermediate at $-0.8 \mathrm{~V}_{\mathrm{SCE}}$ and crystalline at $-0.9 \mathrm{~V}_{\mathrm{SCE}}$. The last one is well correlated with the anodic compound formed in propionate solutions with or without cupric ions, probably cuprite produced after dissolution of a basic copper propionate. The presence of a basic organic compound on copper has been seen before during studies of atmospheric corrosion of copper with acetic acid vapors. ${ }^{2}$

The previous result can be explained in the following way: When increasing the concentration of propionic acid in the air, the aqueous monolayers seek for equilibrium with the new pollutant concentration, consequently rising the propionic acid content in the monolayers (in equilibrium with the aqueous propionate) and progressively diminishing the $\mathrm{pH}$. In this way, the hydroxide initially present in the exposed copper surface is the base for a basic copper propionate, according to the following reaction:

$$
\begin{aligned}
& \mathrm{CuO} \cdot \mathrm{xH}_{2} \mathrm{O}+(2-\mathrm{x}) \mathrm{CH}_{3} \mathrm{CH}_{2} \mathrm{COOH} \rightarrow \\
& \mathrm{Cu}(\mathrm{OH}) \mathrm{x}\left(\mathrm{CH} 3 \mathrm{CH}_{2} \mathrm{COO}\right)_{2-x}+\mathrm{H}_{2} \mathrm{O}
\end{aligned}
$$

At higher propionic acid concentrations in the air (more than $4 \mathrm{ppmv}$ ), the amount of propionate in the aqueous monolayers is also increased, and this solution reaches the deepest layers through cracks (as observed by SEM), making lower the $\mathrm{pH}$ and leading to the conversion of basic propionate to copper propionate monohydrate $\left(\mathrm{Cu}\left(\mathrm{CH}_{3} \mathrm{CH}_{2} \mathrm{COO}\right)_{2} \cdot \mathrm{H}_{2} \mathrm{O}\right)$. This compound is the main constituent of the patinas formed with high concentrations of pollutant. The formation of the copper propionate can be given through the reaction shown in equation $10 .{ }^{9}$

$$
\begin{aligned}
& \mathrm{Cu}(\mathrm{OH})_{\mathrm{x}}\left(\mathrm{CH}_{3} \mathrm{CH}_{2} \mathrm{COO}\right)_{2-\mathrm{x}}+\mathrm{xCH}_{3} \mathrm{CH}_{2} \mathrm{COOH}+(1.2-\mathrm{x}) \\
& \mathrm{H}_{2} \mathrm{O} \rightarrow \mathrm{Cu}\left(\mathrm{CH}_{3} \mathrm{CH}_{2} \mathrm{COO}\right)_{2} \cdot 1.2 \mathrm{H}_{2} \mathrm{O}
\end{aligned}
$$

The final constituents of the soluble patina are the cuprite and the aqueous copper propionate. The arrangement of the cathodic layers (rich in $\mathrm{Cu}_{2} \mathrm{O}$ ) and the anodic layers $\mathrm{Cu}(\mathrm{OH})_{x}\left(\mathrm{CH}_{3} \mathrm{CH}_{2} \mathrm{COO}\right)_{2-\mathrm{x}}$ and $\mathrm{Cu}\left(\mathrm{CH}_{3} \mathrm{CH}_{2} \mathrm{COO}\right)_{2} \cdot \mathrm{H}_{2} \mathrm{O}$ are shown in figure 9 . Therefore, in these coupons the mixtures are $\mathrm{Cu}_{2} \mathrm{O}_{\mathrm{am}} / \mathrm{Cu}_{2} \mathrm{O}_{\text {in }} / \mathrm{Cu}_{2} \mathrm{O}_{\mathrm{cr}} / \mathrm{Cu}(\mathrm{OH})_{x}\left(\mathrm{CH}_{3} \mathrm{CH}_{2} \mathrm{COO}\right)_{2-\mathrm{x}}$.

Finally, cathodic reduction curves evidence the high solubility of the propionate compounds and shows that the main constituents obtained in the inner part of the patina is crystalline copper (I) oxide.

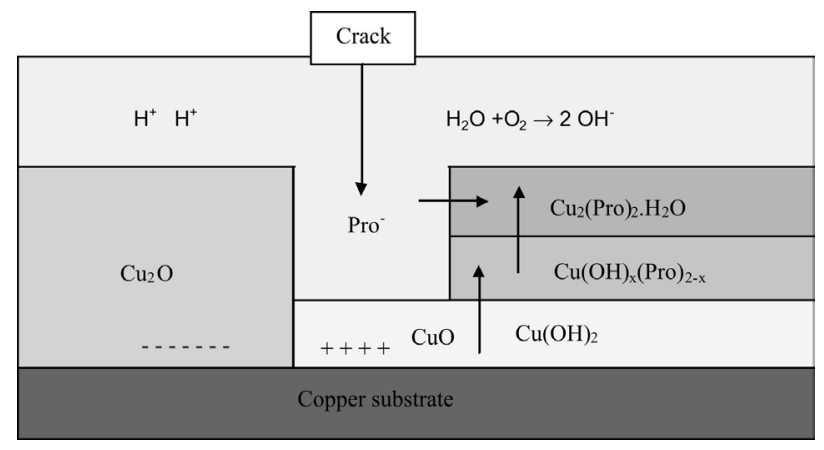

Figure 9. Schematic model of the cathodic and anodic regions for copper coupon exposed to 20 ppmv for 21 days and $100 \% \mathrm{RH}$.

\section{Conclusions}

From the results obtained here, the deterioration of copper in presence of propionic acid vapors can be explained through the following mechanism: The first oxide layer that covers the surface of copper and which is instantly formed is cuprite $\left(\mathrm{Cu}_{2} \mathrm{O}\right)$. This compound, in presence of adsorbed water is oxidized to tenorite $(\mathrm{CuO})$ simultaneously with $\mathrm{pH}$ increase. The hydration of the tenorite layer induces the formation of a hydroxide such as $\mathrm{CuO} \cdot \mathrm{xH}_{2} \mathrm{O}$. As the pollutant level increased in the atmosphere, a basic propionate of the type $\mathrm{Cu}(\mathrm{OH})_{x}\left(\mathrm{CH}_{3} \mathrm{CH}_{2} \mathrm{COO}\right)_{2-\mathrm{x}}$ is formed. Higher concentrations of propionic acid in the atmosphere acidify further the monolayers and a new compound $\mathrm{Cu}\left(\mathrm{CH}_{3} \mathrm{CH}_{2} \mathrm{COO}\right)_{2} \cdot \mathrm{H}_{2} \mathrm{O}$ begins to precipitate at low $\mathrm{pH}$. This is the main constituent of the green olive soluble patina formed under these conditions.

\section{Acknowledgments}

The authors express their gratefulness to the project COLCIENCIAS 1115 - 11500 and to TROPICORRTropicalización de Materiales Electro-Electrónicos for the financial support of the study. Special thanks to Dr. J. Calderón for portuguese translation.

\section{References}

1. Echavarría, A.; Echeverria, F.; Arroyave, C.; Cano, E.; Bastidas, J. M.; Corros. Rev. 2004, 21, 395.

2. Cano, E.; Bastidas, J. M.; Can. Metall. Q. 2002, 41, 327.

3. Lopez-Delgado, J. E.; Cano, E.; Bastidas, J. M.; López, F. A.; J. Electrochem. Soc. 1998, 145, 4140.

4. Bastidas, J. M.; López-Delgado, A.; Cano, E.; Polo, J. L.; López, F. A.; J. Electrochem. Soc. 2000, 147, 999.

5. Cano, E.; López, F. M.; Simancas, J.; Bastidas, J. M.; J. Electrochem. Soc. 2001, 148, E26. 
6. Cano, E.; Mora, E. M.; Ascaray, H.; Bastidas, J. M.; J. Electrochem. Soc. 2004, 151, B207.

7. Cano, E.; Bastidas, J. M.; Polo, J. L.; Mora, N.; J. Electrochem. Soc. 2001, 148, B431.

8. Cano, E.; Mora, E.; Ascaray, H.; López-Caballero, J.; Bastidas, J. M.; Proceedings of Latincorr 2003, Santiago de Chile, Chile, 2003.

9. Cano, E.; Polo, J.; Kong, D.; Mora, E.; López-Caballero, J.; Bastidas, J. M.; Proceedings of the IX Conference of Materials Science \& Technology, Madrid, España, 2003.

10. Lucero, D.; Atmos. Environ. 1972, 6, 943.

11. Pourbaix, M.; Atlas of Electrochemical Equilibria in Aqueous Solutions, $2^{\text {nd }}$ ed., NACE: Houston, 1974.

12. Echavarría, A.; PhD Thesis, Universidad de Antioquia, Colombia, 2004.

13. Deutscher, R. L; Woods. R; J. Appl. Electrochem. 1986, 16, 413.

14. Rickett, B. I; Payer,J. H.; J. Electrochem. Soc. 1995, 142, 3713.

15. Itoh, J; Sasaki, T; Ohtsuka, T; Corros. Sci. 2000, 42, 1539.

16. Lee, S; Staehle, R. W.; J. Electrochem. Soc. 1995,142, 2189.

17. Persson, D; Leygraf, C; J. Electrochem. Soc. 1993, 140, 1256.
18. Lenglet, M.; Kartouni, K.; Delahaye, D.; J. Appl. Electrochem. 1991, 21, 697.

19. Perrin, C.; Simon, D.; Mollimard, M.T.; Baillif, P.; Bardolle, J.; J. Chimie Phys. 1984, 81, 39.

20. Rice, D. W.; Peterson, P.; Rigby, E. B.; Phipps, P. B.; Cappell, R. J.; Tremoureux, R.; J. Electrochem. Soc. 1981, 128, 275.

21. Tran, T.; Fiaud, C.; Sutter, E.; Villanova, A.; Corros. Sci. 2003, $45,2787$.

22. Kunze, J.; Maurice, V.; Klein, L.; Strehblow, H.; Marcus, P.; Corros. Sci. 2004, 46, 245.

23. Pourbaix, M.; Lecciones de Corrosión Electroquímica, Instituto Español de Corrosión y Protección: Madrid, 1987.

24. Drogowska, M.; Brossard, L.; Menard, H.; Corrosion 1987, 43, 549.

25. Gómez, J; Castaño, J; Echavarría, A; Palacio, L; Echeverría, F; Arroyave, C; Bastidas, J. M; Proceedings of $5^{\text {th }}$ Latincorr Corrosion Congress, Santiago de Chile, Chile, 2003.

Received: February 22, 2008

Web Release Date: November 6, 2009 